\title{
Physical injury stimulates aerobic methane emissions from terrestrial plants
}

\author{
Z.-P. Wang ${ }^{1}$, J. Gulledge ${ }^{2,3}$, J.-Q. Zheng ${ }^{1}$, W. Liu ${ }^{1}$, L.-H. Li ${ }^{1}$, and X.-G. Han ${ }^{1}$ \\ ${ }^{1}$ State Key Laboratory of Vegetation and Environmental Change, Institute of Botany, Chinese Academy of Sciences, \\ Nanxincun 20, Xiangshan, Beijing 100093, China \\ ${ }^{2}$ Department of Zoology and Physiology, University of Wyoming, Laramie, WY, USA \\ ${ }^{3}$ Pew Center on Global Climate Change, 2101 Wilson Blvd., Arlington, Virginia, USA
}

Received: 21 November 2008 - Published in Biogeosciences Discuss.: 29 January 200

Revised: 7 April 2009 - Accepted: 7 April 2009 - Published: 17 April 2009

\begin{abstract}
Physical injury is common in terrestrial plants as a result of grazing, harvesting, trampling, and extreme weather events. Previous studies demonstrated enhanced emission of non-microbial $\mathrm{CH}_{4}$ under aerobic conditions from plant tissues when they were exposed to increasing UV radiation and temperature. Since physical injury is also a form of environmental stress, we sought to determine whether it would also affect $\mathrm{CH}_{4}$ emissions from plants. Physical injury (cutting) stimulated $\mathrm{CH}_{4}$ emission from fresh twigs of Artemisia species under aerobic conditions. More cutting resulted in more $\mathrm{CH}_{4}$ emissions. Hypoxia also enhanced $\mathrm{CH}_{4}$ emission from both uncut and cut Artemisia frigida twigs. Physical injury typically results in cell wall degradation, which may either stimulate formation of reactive oxygen species (ROS) or decrease scavenging of them. Increased ROS activity might explain increased $\mathrm{CH}_{4}$ emission in response to physical injury and other forms of stress. There were significant differences in $\mathrm{CH}_{4}$ emissions among 10 species of Artemisia, with some species emitting no detectable $\mathrm{CH}_{4}$ under any circumstances. Consequently, $\mathrm{CH}_{4}$ emissions may be speciesdependent and therefore difficult to estimate in nature based on total plant biomass. Our results and those of previous studies suggest that a variety of environmental stresses stimulate $\mathrm{CH}_{4}$ emission from a wide variety of plant species. Global change processes, including climate change, depletion of stratospheric ozone, increasing ground-level ozone, spread of plant pests, and land-use changes, could cause more stress in plants on a global scale, potentially stimulating more $\mathrm{CH}_{4}$ emission globally.
\end{abstract}

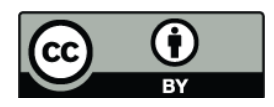

Correspondence to: Z.-P. Wang (wangzp5@ibcas.ac.cn)

\section{Introduction}

Methane $\left(\mathrm{CH}_{4}\right)$ is an important atmospheric trace gas, contributing to global warming and atmospheric redox chemistry. Traditionally, the only known biological source of $\mathrm{CH}_{4}$ was a limited group of obligately anaerobic prokaryotes called methanogens. However, a recent study (Keppler et al., 2006) reported aerobic $\mathrm{CH}_{4}$ emission from plants by an unrecognized, non-microbial mechanism, a result that has been controversial (Schiermeier, 2006; Dueck and van der Werf, 2008). The controversy has focused mainly on two scientific aspects: (i) the as yet unidentified mechanism(s) of $\mathrm{CH}_{4}$ formation in plants, without which the source cannot be confirmed with full confidence; and (ii) how much, if at all, this plant source contributes to the global $\mathrm{CH}_{4}$ budget.

Some studies (Dueck et al., 2007; Beerling et al., 2008; Kirschbaum and Walcroff, 2008; Nisbet et al., 2009) observed no substantial aerobic $\mathrm{CH}_{4}$ emission from plants. However, six independent studies (Keppler et al., 2008; McLeod et al., 2008; Vigano et al., 2008; Wang et al., 2008; Brüggemann et al., 2009; Messenger et al., 2009) did detect $\mathrm{CH}_{4}$ emission from plant tissues/compounds under aerobic conditions in the laboratory. Several studies used isotope signature analysis to confirm that the $\mathrm{CH}_{4}$ originated directly from plant tissues/compounds rather than from microbial methanogenesis (Keppler et al., 2008; Wang et al., 2008; Brüggemann et al., 2009). Field observations (do Carmo et al., 2006; Crutzen et al., 2006; Sanhueza and Donoso, 2006; Sinha et al., 2007; Cao et al., 2008) and satellite measurements (Frankenberg et al., 2005, 2008; Miller et al., 2007) also provided indirect evidence for the possibility of aerobic $\mathrm{CH}_{4}$ emissions by plants in the field but did not verify the source. Keppler et al. (2006) initially estimated aerobic $\mathrm{CH}_{4}$ emission by plants to be in the range of $62-236 \mathrm{Tg} \mathrm{CH}_{4} \mathrm{y}^{-1}$,

Published by Copernicus Publications on behalf of the European Geosciences Union. 
about $10-40 \%$ of the total annual source. Based on a variety of constraints, subsequent analyses yielded lower but potentially still environmentally important source strengths (Houweling et al., 2006; Parsons et al., 2006; Kirschbaum et al., 2006, 2007; Butenhoff and Khalil, 2007; Ferretti et al., 2007).

As one potential constraint on source strength, Dueck and van der Werf (2008) suggested that most species of plants do not actively emit $\mathrm{CH}_{4}$ in the field. Consistent with this suggestion, Wang et al. (2008) observed $\mathrm{CH}_{4}$ emission from several upland shrub species but not from a much larger number of herb species from the same grassland ecosystem. Hence, it is possible that some of the negative results in other studies arise from differences in species examined. For example, Kirschbaum and Walcroft (2008) observed no substantial $\mathrm{CH}_{4}$ emission from Artemisia absinthium. Hence, aerobic $\mathrm{CH}_{4}$ emission might vary across species, even among close relatives. Some negative results could still arise from methodological differences as suggested previously (Wang et al., 2008).

Some studies found that the rate of $\mathrm{CH}_{4}$ production is strongly affected by environmental variables that can induce physiological stress. $\mathrm{CH}_{4}$ emission from plants increased linearly with UV radiation and/or temperature (Keppler et al., 2006; McLeod et al., 2008; Vigano et al., 2008). Physical injury as an environmental stress is common in terrestrial plants. For example, machines harvest crops; insects and ruminants graze leaves and twigs; and strong winds break twigs and detach leaves from stems. In relation to physiological stress, McLeod et al. (2008) suggested that reactive oxygen species (ROS) may have a role in $\mathrm{CH}_{4}$ formation by plants. It is possible therefore that aerobic $\mathrm{CH}_{4}$ emission from plants may be affected by $\mathrm{O}_{2}$ stress or any other stress leading to ROS production.

In this study, we examined the effect of physical injury and hypoxia on $\mathrm{CH}_{4}$ emissions from 10 species of the Artemisia genus sampled from the grasslands of Inner Mongolia.

\section{Materials and methods}

\subsection{Site description}

Fresh plants were collected from the upland grasslands of the Xilin River basin in August 2008. The climate is semiarid, temperate, and continental, with a mean annual temperature of $\sim 0.6^{\circ} \mathrm{C}$. The coldest monthly mean temperature is $-21.4^{\circ} \mathrm{C}$ in January, and the warmest is $18.5^{\circ} \mathrm{C}$ in July. The mean annual precipitation is about $350 \mathrm{~mm}$, with a rainy season between mid-June and mid-September. Approximately $10 \%$ of precipitation falls as snow. The growing season extends from late April to early October. Detailed descriptions of the Xilin River basin have been published elsewhere (Wang et al., 2005).

\subsection{Laboratory incubation}

This study examined $\mathrm{CH}_{4}$ emission in closed-chamber laboratory incubations from fresh twigs of Artemisia genus species indigenous to the Xilin River basin. All species examined were xerophytes (arid-adapted plants) from upland habitats with well-drained soils that exhibit net $\mathrm{CH}_{4}$ consumption from the atmosphere (Wang et al., 2005) and therefore having little if any soil methanogenesis. A previous study (Wang et al., 2008) used isotope signature analysis to confirm that the $\mathrm{CH}_{4}$ emitted from the shrub Artemisia frigida (note that this species was mislabeled as Achillea frigida in Wang et al., 2008) was derived directly from plant tissues. We examined the effect of physical injury (simulated by cutting) on $\mathrm{CH}_{4}$ emission rates from all Artemisia species we found in the Xilin River basin (10 species total). All species were analyzed under aerobic conditions (ambient laboratory air) and A. frigida was also examined under hypoxic conditions. In order to exclude potentially complicating factors from whole plants, such as soil contamination and logistical difficulties with assaying large amounts of biomass, we restricted this work to detached twigs consisting of leaves and stems/petioles. Laboratory incubations were conducted in the dark at an ambient temperature of 24 $26^{\circ} \mathrm{C}$. There were triplicate samples for each treatment group described below.

Fresh twigs were sampled early in the morning (6:007:00 a.m. local time) preceding each measurement event. Samples were placed in plastic bags and transported to the laboratory immediately after sampling. Total time for harvest and transport to the laboratory was approximately $10 \mathrm{~min}$. The twigs were washed in deionized water and air-dried for about $0.5 \mathrm{~h}$. Four grams of air-dried fresh twigs (5$8 \mathrm{~cm}$ length) were either sealed immediately in a gastight serum bottle with a butyl rubber stopper (diameter $20 \mathrm{~mm}$ ) or cut into $5-\mathrm{mm}$ (moderate cutting) or $1-\mathrm{mm}$ (severe cutting) segments and allowed to vent for $10 \mathrm{~min}$ before being sealed in a bottle. To ensure representativeness, we combined twigs from different plants and randomly mixed them in the bottles. Each sample (i.e. one serum bottle) contained five to ten twigs. Both leaves and stems/petioles were cut. To test whether stems and leaves both emitted $\mathrm{CH}_{4}$, stem ends of detached A. frigida were sealed with silicone sealant as a separate treatment group. To establish hypoxic conditions, the bottle was immediately sealed with a butyl rubber stopper and flushed with pure nitrogen $\left(400 \mathrm{ml} \mathrm{min}^{-1}\right.$ for $5 \mathrm{~min}$ ) from a compressed nitrogen cylinder using "inletoutlet" needles inserted through the stopper. Parallel blanks were used to test whether the background $\mathrm{CH}_{4}$ concentrations in the bottles changed in the absence of plant material. The initial $\mathrm{CH}_{4}$ concentrations were measured immediately after sealing.

In order to examine the relationship between $\mathrm{CH}_{4}$ emission and respiration, $\mathrm{CO}_{2}$ release rate was measured in the dark. One gram of fresh twigs (5-8 cm length) of $A$. frigida 
was placed into a $120-\mathrm{ml}$ serum bottle $(n=3)$. Because the $\mathrm{CO}_{2}$ accumulation in the bottle was high relative to the detection range, incubations lasted approximately $15 \mathrm{~min}$. After sampling, the bottle was opened to the ambient atmosphere until the next sampling. Samples were incubated in the dark at an ambient temperature of $22-24^{\circ} \mathrm{C}$.

\section{3 $\mathrm{CH}_{4}$ and $\mathrm{CO}_{2}$ flux measurement}

$\mathrm{CH}_{4}$ and $\mathrm{CO}_{2}$ concentrations were analyzed at various time intervals using a Hewlett-Packard 5890 Series II gas chromatograph equipped with a flame-ionization detector operated at $200^{\circ} \mathrm{C}$, a $2-\mathrm{m}$ stainless steel column packed with 13 XMS (60/80 mesh) for $\mathrm{CH}_{4}$ analysis, and a 2-m stainless steel column packed with Porapak Q (60/80 mesh) for $\mathrm{CO}_{2}$ analysis. The column oven temperature was $55^{\circ} \mathrm{C}$, and the carrier gas was $\mathrm{N}_{2}$ flowing at $30 \mathrm{ml} \mathrm{min}^{-1}$. A 6$\mathrm{ml}$ gas sample was withdrawn from the $120-\mathrm{ml}$ serum bottle by syringe and immediately replaced by $6 \mathrm{ml}$ of laboratory air (aerobic conditions) or $\mathrm{N}_{2}$ (hypoxic conditions) to maintain headspace pressure. Certified $\mathrm{CH}_{4}$ and $\mathrm{CO}_{2}$ standards (China National Research Center for Certified Reference Materials, Beijing) were used for calibration. At the end of each incubation, biomass was determined as ovendried weight $\left(60^{\circ} \mathrm{C}\right.$ for $\left.48 \mathrm{~h}\right)$.

\subsection{Statistical analysis}

Statistical analysis was performed using the SAS (Statistical Analysis System) program (SAS, 1999). Duncan's multiple range test was employed for mean separation of $\mathrm{CH}_{4}$ emission rates among treatments at $P<0.05$. One-way analysis of variance (ANOVA) was used to evaluate statistical difference in the $\mathrm{CH}_{4}$ emission rates among different injuries or between aerobic and hypoxic conditions.

\section{Results}

Cutting, a simulated physical injury, stimulated $\mathrm{CH}_{4}$ emission from fresh twigs of $A$. frigida (Fig. 1). $\mathrm{CH}_{4}$ concentrations increased linearly with time in all treatments with the exception of the blank, indicating that the twigs constantly emitted $\mathrm{CH}_{4}$ throughout the $\sim 24-\mathrm{h}$ incubation. The emission rates were higher in cut twigs than uncut twigs $(P<0.05$, $n=3$ ), and twigs with severe cutting had higher emission rates than twigs with moderate cutting $(P<0.05, n=3)$. Sealing the stem ends of detached twigs did not have a measurable effect on $\mathrm{CH}_{4}$ emission, suggesting that $\mathrm{CH}_{4}$ was emitted from leaves, not stems. Under hypoxic conditions, $\mathrm{CH}_{4}$ concentrations increased linearly with time and cutting increased the rate of $\mathrm{CH}_{4}$ emission (Fig. 2a). $\mathrm{CH}_{4}$ emissions were significantly higher $(P<0.05, n=3)$ under hypoxic conditions than under aerobic conditions for both cut and uncut twigs (Fig. 2b).
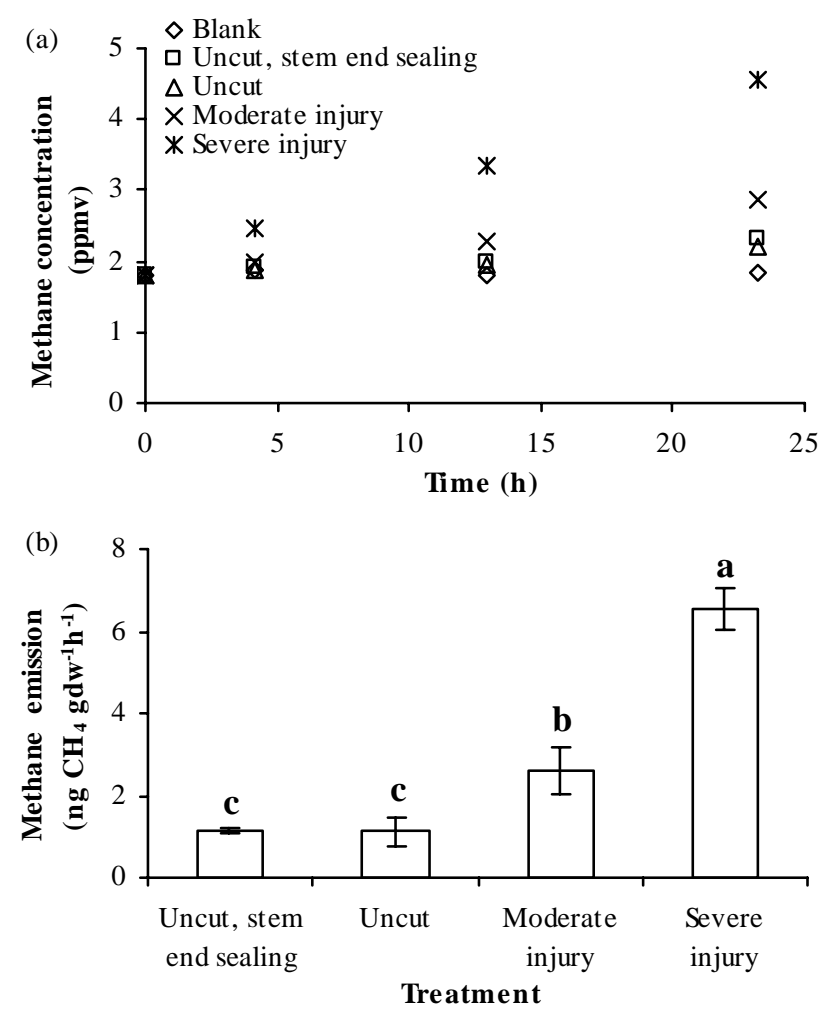

Fig. 1. Effect of physical injury (cutting) on $\mathrm{CH}_{4}$ emission from fresh twigs of Artemisia frigida. (a) $\mathrm{CH}_{4}$ accumulation over time. (b) $\mathrm{CH}_{4}$ emission rates showing standard deviations $(n=3)$ and statistically significant differences $(P<0.05)$ among treatments indicated by different letters. The $\mathrm{CH}_{4}$ emission rates were calculated using the $\mathrm{CH}_{4}$ accumulation over time. Treatments: Blank, Uncut twigs with stem ends sealed with silicone sealant, Uncut twigs with stem ends not sealed, Moderate injury (twigs cut into $5 \mathrm{~mm}$ segments), and Severe injury (twigs cut into $1 \mathrm{~mm}$ segments).

Dark respiration decreased over time in all treatments but did not cease entirely during incubations (Fig. 3). Respiration rates were about $50 \%$ higher in cut than in uncut twigs under aerobic conditions (Fig. 3a). $\mathrm{CO}_{2}$ production was about 3- to 10-fold slower and decreased more over time under hypoxic than under aerobic conditions (Fig. 3b). In contrast to $\mathrm{CH}_{4}$ emission, which was increased by cutting under both aerobic and hypoxic conditions, $\mathrm{CO}_{2}$ emission was unaffected or deceased in response to cutting under hypoxic conditions.

Table 1 lists the $\mathrm{CH}_{4}$ emission rates under aerobic conditions from fresh twigs of 10 Artemisia species sampled from the upland areas of the Xilin River basin. Four species were shrubs and six species were herbs. Only 1 species, A. frigida, emitted detectable amounts of $\mathrm{CH}_{4}$ without cutting. Eight species were further tested for $\mathrm{CH}_{4}$ emission after cutting, but only five, two shrub species including A. frigida and three herb species, emitted $\mathrm{CH}_{4}$ continuously throughout the 24-h incubation. A. frigida exhibited the highest emission rates. 

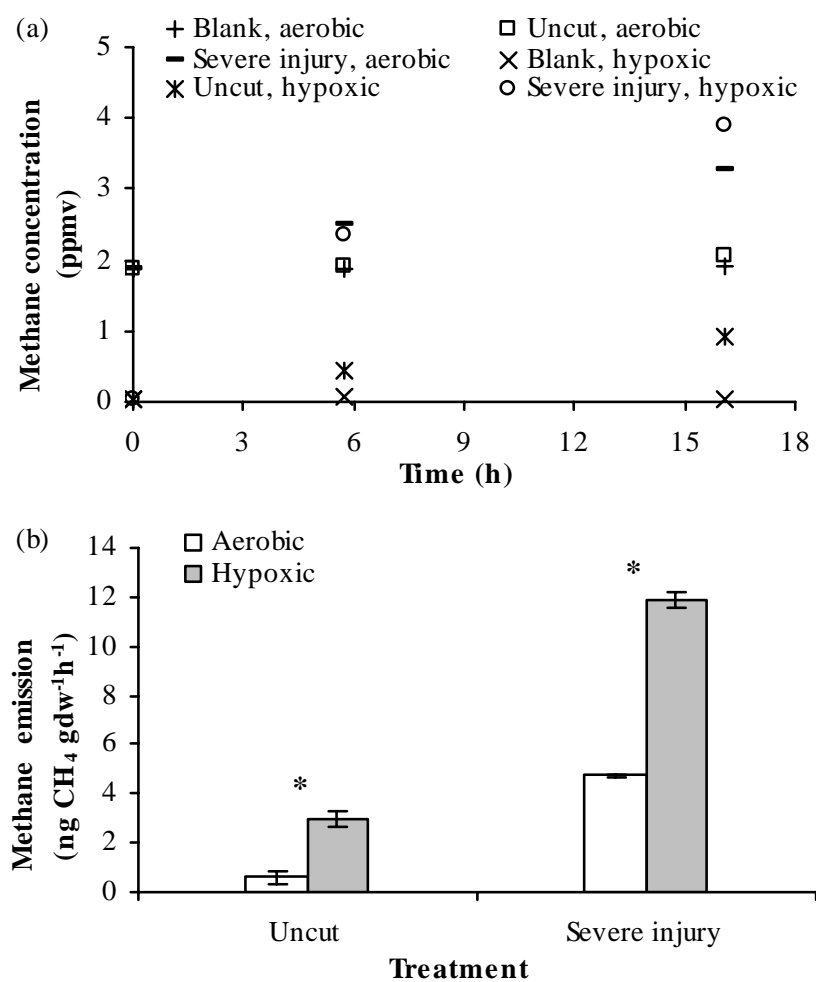

Fig. 2. Effect of hypoxia on $\mathrm{CH}_{4}$ emission from fresh twigs of Artemisia frigida. (a) $\mathrm{CH}_{4}$ accumulation over time. Initial $\mathrm{CH}_{4}$ concentrations were approximately 1.9 and 0 ppmv in aerobic and hypoxic conditions, respectively. (b) $\mathrm{CH}_{4}$ emission rates (mean \pm standard deviation; $n=3$; $*$ indicates statistically significant difference at $P<0.05$ between aerobic and hypoxic conditions). The $\mathrm{CH}_{4}$ emission rates were calculated using the $\mathrm{CH}_{4}$ accumulation over time. Treatments: Blank, Uncut twigs, Severe injured twigs in aerobic conditions, Blank in hypoxic conditions, Uncut twigs in hypoxic conditions, and Severe injured twigs in hypoxic conditions (twigs cut into $1 \mathrm{~mm}$ segments).

\section{Discussion}

\subsection{Environmental stress stimulates $\mathrm{CH}_{4}$ emission from plants}

Many wetland plants (hydrophytes) transport $\mathrm{CH}_{4}$ produced by anaerobic soil microorganisms to the atmosphere through their roots and stems (Schimel et al., 1995). Previously, we showed that microbial $\mathrm{CH}_{4}$ stored in the stems of hydrophytes is eliminated within minutes after cutting, whereas $\mathrm{CH}_{4}$ derived directly from plant compounds is emitted continuously over many hours; microbial and plant-derived $\mathrm{CH}_{4}$ were distinguished by their distinct $\delta^{13} \mathrm{C}$ signatures (Wang et al., 2008). Concurring studies have found that neither adsorption-desorption processes nor $\mathrm{CH}_{4}$ stored within intercellular air spaces are responsible for the observed $\mathrm{CH}_{4}$ emissions (Kirschbaum et al., 2007; Kirschbaum and Walcroft, 2008; Vigano et al., 2008). In the present study, physi-
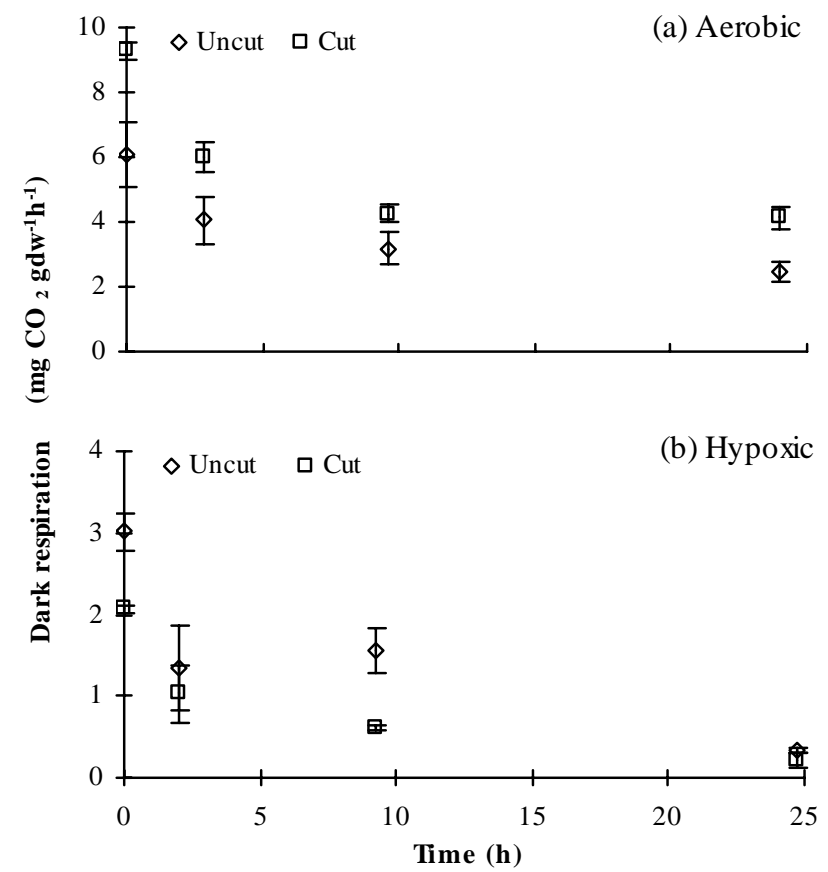

Fig. 3. Dark respiration from fresh twigs of Artemisia frigida Treatments are (a) Uncut twigs and cut twigs in aerobic conditions and (b) Uncut twigs and cut twigs in hypoxic conditions. The $\mathrm{CO}_{2}$ release rate is mean \pm 1 standard deviation, $n=3$.

cal injury elevated the rate of $\mathrm{CH}_{4}$ emission from fresh twigs of A. frigida continuously for $\sim 24-\mathrm{h}$ (Fig. 1), indicating that physical injury released $\mathrm{CH}_{4}$ from plant compounds by an as yet unidentified mechanism.

Hypoxia also induced higher rates of $\mathrm{CH}_{4}$ emission from A. frigida (Fig. 2). Although the initial $\mathrm{CH}_{4}$ concentration was lower in the hypoxic incubations because of flushing with $\mathrm{N}_{2}$, we found previously that $\mathrm{CH}_{4}$ emission rates were indistinguishable in $\mathrm{CH}_{4}$-free air and in ambient atmospheric $\mathrm{CH}_{4}$ (Wang et al., 2008). Vigano et al. (2008) also found that emission rates were independent of background $\mathrm{CH}_{4}$ concentration in an incubation system that continuously replaced the atmosphere. Hence, the significant difference in emission rates under aerobic and hypoxic conditions observed here likely resulted from the difference in $\mathrm{O}_{2}$ concentrations and not from the difference in initial $\mathrm{CH}_{4}$ concentrations. Hypoxia induces stress through the accumulation of toxic metabolic products, the lowering of energy charge, and the lack of substrates for respiration (Drew, 1997). Xerophytes, such as the Artemisia species examined here, would probably be particularly susceptible to hypoxia stress since they are adapted to well- aerated soils and are not accustomed to hypoxic conditions.

Previous studies have shown that UV radiation and rising temperature independently stimulate $\mathrm{CH}_{4}$ emission from plants (Keppler et al., 2006; McLeod et al., 2008; Vigano et al., 2008). Keppler et al. (2006) observed an exponential 
Table 1. $\mathrm{CH}_{4}$ emissions from Artemisia species sampled from the upland grasslands of the Xilin River basin ${ }^{\mathrm{a}}$.

\begin{tabular}{|c|c|c|c|c|}
\hline \multirow[t]{2}{*}{ Morphotype } & \multirow[t]{2}{*}{ Species } & \multirow[t]{2}{*}{ Incubated tissue ${ }^{b}$} & \multicolumn{2}{|c|}{$\mathrm{CH}_{4}$ emission $\left(\mathrm{ng} \mathrm{CH} \mathrm{Cdw}^{-1} \mathrm{~h}^{-1}\right)$} \\
\hline & & & Uncut & Cut \\
\hline \multirow[t]{4}{*}{ Shrub } & Artemisia frigida Willd. & twigs (leaves and stems) & $0.38 \pm 0.11$ & $4.59 \pm 0.45$ \\
\hline & Artemisia intramongolica $\mathrm{H}$. C. Fu & twigs (leaves and stems) & ND & $1.24 \pm 0.04$ \\
\hline & Artemisia gmelinii var. vestita Nakai & twigs (leaves and stems) & ND & ND \\
\hline & Artemisia gmelinii Web. ex Stechm & twigs (leaves and stems) & ND & ND \\
\hline \multirow[t]{6}{*}{ Herb } & Artemisia argyi Levl. et Vant. & twigs (leaf and petiole) & ND & $3.25 \pm 0.80$ \\
\hline & Artemisia eriopoda Bunge & twigs (leaf and petiole) & ND & $0.45 \pm 0.15$ \\
\hline & Artemisia sieversiana Willd. & twigs (leaf and petiole) & ND & $0.91 \pm 0.22$ \\
\hline & Artemisia laciniata Willd. & twigs (leaves and stems) & ND & ND \\
\hline & Artemisia rubripes Nakai & twigs (leaf and petiole) & ND & NM \\
\hline & Artemisia scoparia Wald. et kit. & twigs (leaves and stems) & ND & NM \\
\hline
\end{tabular}

${ }^{a}$ Fresh plant tissues were sampled during 17-18 August 2008. $\mathrm{CH}_{4}$ emissions were measured for uncut (but detached) and cut plant tissues, respectively, incubated in the dark at room temperature of $21-24^{\circ} \mathrm{C}$ for approximately $24 \mathrm{~h}$ with initially ambient $\mathrm{CH}_{4}$ concentration in air. Emission rate is mean \pm standard deviation $(n=3)$. ND indicates that no $\mathrm{CH}_{4}$ emission was detected or was too weak to quantify from linear change in $\mathrm{CH}_{4}$ concentrations within $24 \mathrm{~h}$, while $\mathrm{NM}$ was no measurement.

$\mathrm{b}$ Bracket shows one or more plant organs per twig.

increase in emission rates with rising temperature from 30 to $70^{\circ} \mathrm{C}$, which is inconsistent with a microbial or other enzymatic process. Vigano et al. (2008) similarly observed increasing $\mathrm{CH}_{4}$ emission rates with increasing temperature up to $60^{\circ} \mathrm{C}$ in the dark. In our study, $\mathrm{CH}_{4}$ emission increased with increasing physical injury in the dark. Hence, UV radiation, rising temperature, physical injury, and hypoxia all stimulate $\mathrm{CH}_{4}$ emission from plant tissues, suggesting that environmental stress in general may increase $\mathrm{CH}_{4}$ emission from plants.

\subsection{Mechanistic implications of stress}

In this study, physical injury stimulated dark respiration under aerobic conditions (Fig. 3). During physiological stress, respiratory electron transport can give rise to celldamaging ROS, including hydrogen peroxide $\left(\mathrm{H}_{2} \mathrm{O}_{2}\right)$, superoxide ion $\left(\mathrm{O}_{2}^{-}\right)$, hydroperoxyl radical $\left(\mathrm{HO}_{2}\right)$, hydroxyl radical $(\mathrm{OH})$, and singlet oxygen $\left({ }^{1} \mathrm{O}_{2}\right)$. ROS cleave polymer chains in site-specific reactions (Scandalios, 1993; Fry, 1998; Schweikert et al., 2002; Cheng et al., 2008). Hence, formation of $\mathrm{CH}_{4}$ from plant tissues could result from ROS attacks that cleave methyl groups from plant lignin or pectin (Keppler et al., 2008; McLeod et al., 2008). In a previous study, we found that $\mathrm{CH}_{4}$ emitted continuously from $\mathrm{A}$. frigida leaves had a carbon isotope signature consistent with methoxyl groups of plant pectin (Wang et al., 2008), and Keppler et al. (2006) found evidence for pectin-derived $\mathrm{CH}_{4}$ emitted by other plant species. The pool of methoxyl groups in pectin is large in comparison to adsorbed/stored $\mathrm{CH}_{4}$ and would be available continuously for $\mathrm{CH}_{4}$ formation (Keppler et al., 2006; Vigano et al., 2008), consistent with the results of this study and previous results.
A variety of environmental stressors, such as radiation, herbicides, pathogens, certain injuries, hypoxia, ground-level ozone, and temperature fluctuations, stimulate the formation of ROS in plants (Scandalios, 1992; Crawford and Brandle, 1996). For example, Chen and Qualls (2003) reported an increase of free radical damage during hypoxia, and Lin et al. (2006) observed a decrease of ROS scavenging in plants under flooding (resulting in hypoxia). Physical injury of certain plant tissues initiates a complex series of reactions that largely involve a self-perpetuating wave of free radical generation (Thompson et al., 1987). Hence, repeated observations in several studies of $\mathrm{CH}_{4}$ emission from plants being stimulated by rising temperatures, UV irradiation, hypoxia, and physical injury could be explained by physiological stress leading to ROS formation. This mechanism is distinct from but not mutually exclusive with the mechanism of UV-driven cleavage of methyl groups from plant compounds proposed previously (McLeod et al., 2008; Vigano et al., 2008).

\subsection{Species differences}

In a previous study, we found that several shrubs but no herbs emitted $\mathrm{CH}_{4}$ derived from plant compounds (Wang et al., 2008). In the present study we again detected no $\mathrm{CH}_{4}$ emission from uncut herbs (Table 1). However, cutting injuries stimulated $\mathrm{CH}_{4}$ emission in three out of four herb species that were tested (Table 1). Hence, both shrubs and herbs have the potential to emit $\mathrm{CH}_{4}$ when injured. Even after injury, however, we still detected no $\mathrm{CH}_{4}$ emission from two species of shrub and one species of herb, all belonging to the Artemisia genus (Table 1). Kirschbaum and Walcroft (2008) observed no substantial $\mathrm{CH}_{4}$ emission from another Artemisia species, Artemisia absinthium, in New 
Zealand. Thus, $\mathrm{CH}_{4}$ emissions may be species-dependent, even among closely related species. The differences could reflect variation among leaf structures, UV-screening pigments, UV-photosensitizers, and ROS-scavenging mechanisms (see McLeod et al., 2008), as well as phenology and environmental/experimental conditions.

\section{Conclusions}

Along with other laboratory studies, our results confirm that a wide variety of plant species and functional types can emit $\mathrm{CH}_{4}$ under aerobic conditions and in the absence of likely microbial $\mathrm{CH}_{4}$ sources. However, emission rates vary both among plant species and in different environmental conditions, including hypoxia. Therefore, estimating the contribution of this process to the global $\mathrm{CH}_{4}$ cycle might not be possible based on simple biomass- and temperature-based algorithms (e.g., Keppler et al., 2006; Butenhoff and Khalil, 2007). Similarly, because $\mathrm{CH}_{4}$ emission responds to light, Keppler et al. (2006) used average daily sunshine hours to estimate annual global emissions of $\mathrm{CH}_{4}$ by living plants and leaf litter. However, a wide variety of environmental conditions can stimulate or accelerate $\mathrm{CH}_{4}$ emission from plants in the dark. Because nighttime accounts for half of a plant's life, the global plant-derived $\mathrm{CH}_{4}$ emission stimulated by environmental stressors at night could be an important component of aerobic $\mathrm{CH}_{4}$ emissions.

If stress is a major driver of $\mathrm{CH}_{4}$ emission from plants, then global change processes, such as climate change, stratospheric ozone depletion, increasing ground-level ozone, spread of plant pests, and land-use changes, could increase stress in plants and cause a global increase in $\mathrm{CH}_{4}$ emissions. If so, the role of stress in plant $\mathrm{CH}_{4}$ production in the global $\mathrm{CH}_{4}$ cycle could be important in a changing world. Future studies are needed that focus on in situ measurements, comparisons between stressed and unstressed plants, dark and light $\mathrm{CH}_{4}$ emissions, and interspecies differences.

Acknowledgements. This research was supported by a general program from the National Natural Science Foundation of China (30670402), the State Key Basic Research Development Program of China (2007CB106800), and the funding of State Key Laboratory of Vegetation and Environmental Change.

Edited by: G. Wohlfahrt

\section{References}

Beerling, D. J., Gardiner, T., Leggett, G., Mcleod, A., and Quick, W. P.: Missing methane emissions from leaves of terrestrial plants, Glob. Change Biol., 14, 1-6, 2008.

Brüggemann, N., Meier, R., Steigner, D., Zimmer, I., Louis, S., and Schnitzler, J.-P.: Nonmicrobial aerobic methane emission from poplar shoot cultures under low-light conditions, New Phytol., doi:10.1111/j.1469-8137.2009.02797.x, 2009.
Butenhoff, C. L. and Khalil, M. A. K.: Global methane emissions from terrestrial plants, Environ. Sci. Technol., 41, 4032-4037, 2007.

Cao, G. M., Xu, X. L., Long, R. J., Wang, Q. L., Wang, C. T., Du, Y. G., and Zhao, X. Q.: Methane emissions by alpine plant communities in the Qinghai-Tibet Plateau, Biol. Lett.-UK, 4, 681-684, 2008.

do Carmo, J. B., Keller, M., Dias, J. D., de Camargo, P. B., and Crill, P.: A source of methane from upland forests in the Brazilian Amazon, Geophys. Res. Lett., 33, L04809, doi:10.1029/2005GL025436, 2006.

Chen, H. J. and Qualls, R. G.: Anaerobic metabolism in the roots of seedlings of the invasive exotic Lepidium latifolium, Environ. Exp. Bot., 50, 29-40, 2003.

Cheng, G. P., Duan, X. W., Yang, B., Jiang, Y. M., Lu, W. J., Luo, Y. B., and Jiang, W. B.: Effect of hydroxyl radical on the scission of cellular wall polysaccharides in vitro of banana fruit at various ripening stages, Acta Physiol. Plant, 30, 257-263, 2008.

Crawford, R. M. M. and Brandle, R.: Oxygen deprivative stress in a changing environment, J. Exp. Bot., 47, 145-159, 1996.

Crutzen, P. J., Sanhueza, E., and Brenninkmeijer, C. A. M.: Methane production from mixed tropical savanna and forest vegetation in Venezuela, Atmos. Chem. Phys. Discuss., 6, 30933097, 2006,

http://www.atmos-chem-phys-discuss.net/6/3093/2006/.

Drew, M. C.: Oxygen deficiency and root metabolism: injury and acclimation under hypoxia and anoxia, Ann. Rev. Plant Physiol. Plant Mole. Biol., 48, 223-250, 1997.

Dueck, T. A., de Visser, R., Poorter, H., Persijn, S., Gorissen, A., de Visser, W., Schapendonk, A., Verhagen, J., Snel, J., Harren, F. J. M., Ngai, A. K. Y., Verstappen, F., Bouwmeester, H., Voesenek, L. A. C. J., and van der Werf, A.: No evidence for substantial aerobic methane emission by terrestrial plants: a ${ }^{13} \mathrm{C}$-labelling approach, New Phytol., 175, 29-35, 2007.

Dueck, T. and van der Werf, A.: Are plants precursors for methane?, New Phytol., 178, 693-695, 2008.

Ferretti, D. F., Miller, J. B., White, J. W. C., Lassey, K. R., Lowe, D C., and Etheridge, D. M.: Stable isotopes provide revised global limits of aerobic methane emissions from plants, Atmos. Chem. Phys., 7, 237-241, 2007, http://www.atmos-chem-phys.net/7/237/2007/.

Frankenberg, C., Meirink, J. F., van Weele, M., Platt, U., and Wagner, T.: Assessing methane emissions from global space-borne observations, Science, 308, 1010-1014, 2005.

Frankenberg, C., Bergamaschi, P., Butz, A., Houweling, S., Meirink, J. F., Notholt, J., Petersen, A. K., Schrijver, H., Warneke, T., and Aben, I.: Tropical methane emissions: A revised view from SCIAMACHY onboard ENVISAT, Geophys. Res. Lett., 35, L15811, doi:10.1029/2008GL034300, 2008.

Fry, S. C.: Oxidative scission of plant cell wall polysaccharides by ascorbate-induced hydroxyl radicals, Biochem. J., 332, 507-515, 1998.

Houweling, S., Röckmann, T., Aben, I., Keppler, F., Krol, M., Meirink, J. F., Dlugokencky, E. J., and Frankenberg, C.: Atmospheric constraints on global emissions of methane from plants, Geophys. Res. Lett., 33, L15821, doi:10.1029/2006GL026162, 2006.

Keppler, F., Hamilton, J. T. G., Braß, M., and Röckmann, T.: Methane emissions from terrestrial plants under aerobic condi- 
tions, Nature, 439, 187-191, 2006.

Keppler, F., Hamilton, J. T. G., McRoberts, W. C., Vigano, I., Braß, M., and Röckmann, T.: Methoxyl groups of plant pectin as a precursor of atmospheric methane: evidence from deuterium labelling studies, New Phytol., 178, 808-814, 2008.

Kirschbaum, M. U. F., Bruhn, D., Etheridge, D. M., Evans, J. R., Farquhar, G. D., Gifford, R. M., Paul, K. I., and Winters, A. J.: A comment on the quantitative significance of aerobic methane release by plants, Funct. Plant Biol., 33, 521-530, 2006.

Kirschbaum, M. U. F., Niinemets, U., Bruhn, D., and Winters, A. J.: How important is aerobic methane release by plants?, Functional Plant Science and Technology, 1, 138-145, 2007.

Kirschbaum, M. U. F. and Walcroft, A.: No detectable aerobic methane efflux from plant material, nor from adsorption/desorption processes, Biogeosciences, 5, 1551-1558, 2008, http://www.biogeosciences.net/5/1551/2008/.

Lin, K. H., Chao, P. Y., Yang, C. M., Cheng, W. C., Lo, H. F., and Chang, T. R.: The effects of flooding and drought stresses on the antioxidant constituents in sweet potato leaves, Bot. Stud., 47, 417-426, 2006.

McLeod, A. R., Fry, S. C., Loake, G. J., Messenger, D. J., Reay, D. S., Smith, K. A., and Yun, B. W.: Ultraviolet radiation drives methane emissions from terrestrial plant pectins, New Phytol., 180, 124-132, 2008.

Messenger, D. J., McLeod, A. R., and Fry, S. C.: The role of ultraviolet radiation, photosensitizers, reactive oxygen species and ester groups in mechanisms of methane formation from pectin, Plant Cell Environ., 32, 1-9, 2009.

Miller, J. B., Gatti, L. V., d'Amelio, M. T. S., Crotwell, A. M., Dlugokencky, E. J., Bakwin, P., Artaxo, P., and Tans, P. P.: Airborne measurements indicate large methane emissions from the eastern Amazon basin, Geophys. Res. Lett., 34, L10809, doi:10.1029/2006GL029213, 2007.

Nisbet, R. E. R., Fisher, R., Nimmo, R. H., Bendall, D. S., Crill, P. M., Gallego-Sala, A. V., Hornibrook, E. R. C., López-Juez, E., Lowry, D., Nisbet, P. B. R., Shuckburgh, E. F., Sriskantharajah, S., Howe, C. J., and Nisbet, E. G.: Emission of methane from plants, Proceedings of the Royal Society B: Biological Sciences, 276, 1347-1354, 2009.

Parsons, A. J., Newton, P. C. D., Clark, H., and Kelliher, F. M.: Scaling methane emissions from vegetation, Trends Ecol. Evol., 21, 423-424, 2006.
Sanhueza, E. and Donoso, L.: Methane emission from tropical savanna Trachypogon sp. grasses, Atmos. Chem. Phys., 6, 53155319, 2006, http://www.atmos-chem-phys.net/6/5315/2006/.

SAS: SAS/STATk User's Guide Release 8.0 Cary, North Carolina, USA, 1999.

Scandalios, J. G.: Molecular Biology of Free Radical Scavenging Systems, Cold Spring Harbor Laboratory Press, Cold Spring Harbor, New York, 1992.

Scandalios, J. G.: Oxygen stress and superoxide dismutases, Plant Physiol., 101, 7-12, 1993.

Schiermeier, Q.: Methane finding baffles scientists, Nature, 439, 128-128, 2006.

Schimel, J. P.: Plant transport and methane production as controls on methane flux from arctic wet meadow tundra, Biogeochemistry, 28, 183-200, 1995.

Schweikert, C., Liszkay, A., and Schopfer, P.: Polysaccharide degradation by Fenton reaction- or peroxidase-generated hydroxyl radicals in isolated plant cell walls, Phytochemistry, 61, 31-35, 2002.

Sinha, V., Williams, J., Crutzen, P. J., and Lelieveld, J.: Methane emissions from boreal and tropical forest ecosystems derived from in-situ measurements, Atmos. Chem. Phys. Discuss., 7, 14011-14039, 2007, http://www.atmos-chem-phys-discuss.net/7/14011/2007/.

Thompson, J. E., Legge, R. L., and Barber, R. F.: The role of free radicals in senescence and wounding, New Phytol., 105, 317344, 1987.

Vigano, I., van Weelden, H., Holzinger, R., Keppler, F., McLeod, A., and Röckmann, T.: Effect of UV radiation and temperature on the emission of methane from plant biomass and structural components, Biogeosciences, 5, 937-947, 2008, http://www.biogeosciences.net/5/937/2008/.

Wang, Z. P., Han, X. G., Li, L. H., Chen, Q. S., Duan, Y., and Cheng, W.: Methane emission from small wetlands and implications for semiarid region budgets, J. Geophys. Res., 110, D13304, doi:13310.11029/12004JD005548, 2005.

Wang, Z. P., Han, X. G., Wang, G. G., Song, Y., and Gulledge, J.: Aerobic methane emission from plants in the Inner Mongolia steppe, Environ. Sci. Technol., 42, 62-68, 2008. 